\title{
RECYCLED GREEN PE COMPOSITES REINFORCED WITH WOVEN AND RANDOMLY ARRANGED SISAL FIBRES PROCESSED BY HOT COMPRESSION MOULDING
}

\author{
Bruno Dorneles de CASTRO*, Paulo Eustáquio de FARIA, Luciano Machado Gomes VIEIRA, \\ Claudia Victoria CAMPOS RUBIO, Rômulo MAZIERO, \\ Paulo César de Matos RODRIGUES, Juan Carlos CAMPOS RUBIO \\ Federal University of Minas Gerais, Brasil
}

\begin{abstract}
Green plastics are constantly being used to minimize the negative impacts of the polymers made of fossil fuels such as petroleum. Non-renewable petroleum-based products are employed in wide range of human activities, yet plastic waste accumulation represents a serious issue for the environment (Mohd Rafee et al., 2019). On the other hand, the use of natural fibres in composite materials, such as sisal fibres, in substitution for synthetic fibres, has increased considerably. The aim of this study was to develop a low-cost manufacturing process of composites with reuse of polyethylene bags made of sugarcane ethanol (green polyethylene) reinforced with sisal fibres. The hot compression moulding $\left(185^{\circ} \mathrm{C}\right)$ was used to mould composite structural board. Tensile tests were conducted to evaluate the influence of the reinforcement configuration on the mechanical properties of the composites, considering two arrangements: woven fibres in $\left(0^{\circ} / 90^{\circ}\right)$ and randomly arranged. The results indicated that the use of woven sisal fibres in $\left(0^{\circ} / 90^{\circ}\right)$ as reinforcement of the green HDPE showed an increase in the tensile strength (33.30\%) in contrast to the pure traditional HDPE. Randomly arranged sisal fibre-reinforced green HDPE composites showed higher modulus of elasticity than pure traditional HDPE (76.83\%). Composites with woven sisal fibres showed higher values for tensile strength and ultimate strain, and lower modulus of elasticity than composites with randomly arranged sisal fibres. In addition, failure modes of the composites were observed. The results showed the viability of producing these composites by the developed equipment and the potential use of these materials as structural components.
\end{abstract}

Keywords: sustainability; biopolymers; waste plastic; natural fibre

In recent years, aligning composite materials production with sustainable guidelines has been the focus of many studies. The sustainable use of natural resources can be applied to various stages of a product's life cycle, since the extraction and manufacturing to disposal and recycling (Akinyemi et al., 2016). Plati (2019) argues that the concept of sustainability is based on a balance among the economic, environmental and social spheres and that this should be considered an important aspect for humanity, especially with regard to climate change on the planet, as over time.

Within this context, the reuse or the recycling of plastic waste is one of the ways to minimize the environmental impacts generated by the inappropriate disposal. From the environmental view, the economic aspect of this process is emphasized, since plastics have high added value. Thermoplastics, such as PE, are the most used for recycling and are widely applied in engineering (Ahmad and Luyt, 2012).

Polyethylene produced from sugarcane ethanol is called green polyethylene (green PE) because it is produced from renewable source. It is considered an innovative polymer that captures and fixes carbon dioxide from the atmosphere during its production and does not release it back to the environment during its life cycle, contributing to the reduction of greenhouse gases (GHG), as shown in Fig. 1. In addition, green PE is recyclable within the same supply chain as traditional polyethylene (Guilhen et al., 2017).

Moreover, the use of natural fibres instead of synthetic fibres in composite materials has been widely investigated in the last decade. Natural fibres have advantages such as low weight and low cost, and have a renewable nature, they can decompose in a few months, unlike synthetic fibres, which usually decompose many years (Chattopadhyay et al., 2011).

As one of the main uses of natural fibres in terms of the reinforcement of plastics and rubbers stand out increasing quality and commercial application. Sisal fibre-reinforced composites have been more used recently in the automotive and aerospace industries (Choudhury, 2008). Fávaro et al. (2010) evaluated the composites made of post-consumed high-density polyethylene (HDPE) reinforced with short sisal fibres (10\% in weight) and achieved improvements in the modulus of elasticity (approx. 16\%) in contrast to pure HDPE. Zhao et al. (2014) investigated the mechanical properties of randomly arranged sisal fibre-reinforced HDPE composites and found an increase in the modulus of elasticity (88.9\%) when added $20 \%$ of fibres in weight, which showed the applicability of these fibres. Table 1 shows the mechanical 


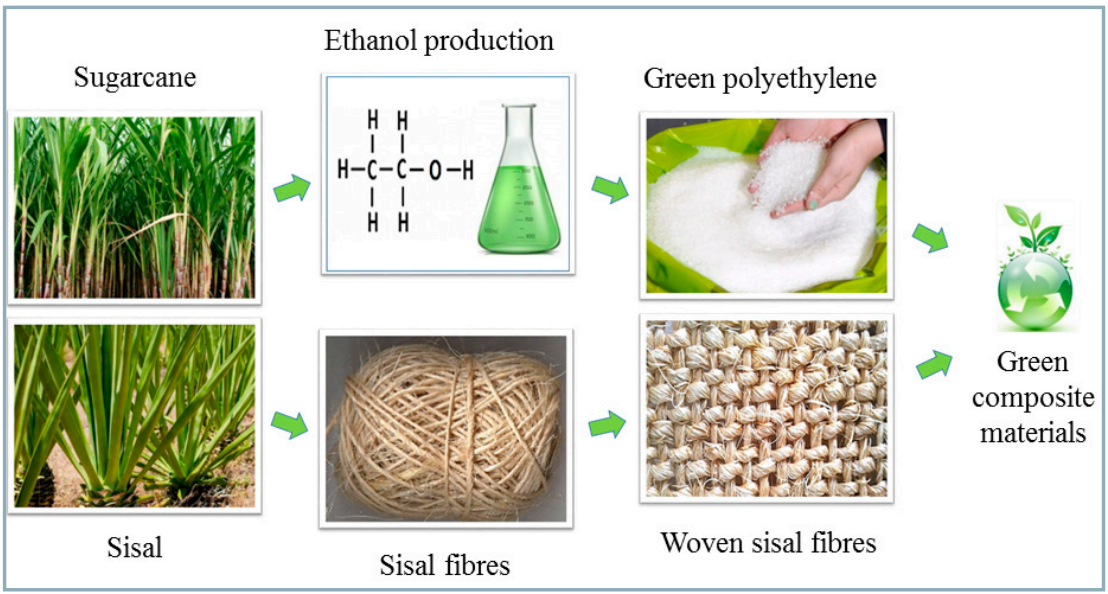

Fig. 1 Production of a woven sisal fibre-reinforced green polyethylene composite

Table 1 Mechanical properties of sisal fibre

\begin{tabular}{|c|c|c|c|c|}
\hline $\begin{array}{c}\text { Density } \\
\left(\mathbf{k g} \cdot \mathbf{m}^{-3}\right)\end{array}$ & $\begin{array}{c}\text { Diameter } \\
(\boldsymbol{\mu m})\end{array}$ & $\begin{array}{c}\text { Tensile strength } \\
(\mathbf{M P a})\end{array}$ & $\begin{array}{c}\text { Modulus of } \\
\text { elasticity (GPa) }\end{array}$ & $\begin{array}{c}\text { Ultimate } \\
\text { strain (\%) }\end{array}$ \\
\hline $1,030-1,450$ & $50-300$ & $346-700$ & $7-22$ & $2.2-14$ \\
\hline
\end{tabular}

properties of sisal fibre according to Ibrahim et al. (2016).

In order to show a possible application of these composites in structural products, this work aimed to develop a low-cost manufacturing process of green composite materials using reused polyethylene bags and sisal fibres as reinforcement (Fig. 1). The values of tensile strength, modulus of elasticity and ultimate strain were obtained by tensile tests (ASTM D638, 2014).

\section{Material and methods}

High-density polyethylene (HDPE) obtained from reused polymeric bags, and sisal fibres were used for the production of composite boards. They were produced from traditional

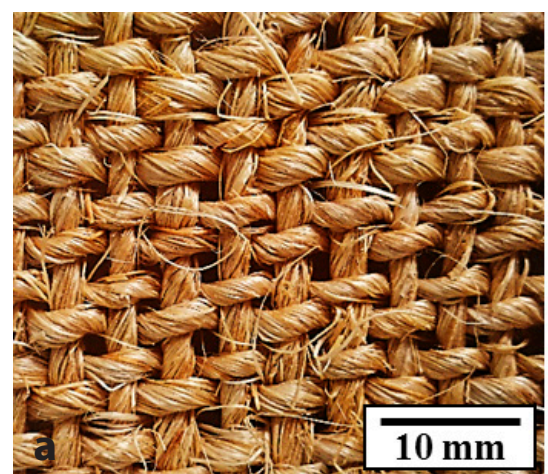

Woven sisal fibres were configured in plain weave, $\left(0^{\circ} / 90^{\circ}\right)$ configuration, type 530/1 yarns, with nearly $2 \mathrm{~mm}$ thickness and gaps between them of approx. $1 \mathrm{~mm}^{2}$ weft yarns. In the random configuration, sisal fibres were arranged multi-directionally, assuring a better isotropic mechanical behaviour.

Composites were manufactured using the 70/30 mass ratio (matrix/ fibre). The mass ratio was selected after preliminary experiments based on Ahmad and Luyt (2012). The boards produced using the $70 / 30$ mass ratio proved to be more efficient in terms of the final thickness. Pure HDPE boards (without reinforcement) were also manufactured. In all experimental conditions, polymeric layers have been produced by stacking plastic films (from polyethylene bags), forming multi-layered plastics. For the standardisation of the same thickness of the boards, the value of the mass required for the pure HDPE board was determined using Eq. 1 as a function of the densities of the materials. An approximate density of $0.95 \mathrm{~g} \cdot \mathrm{cm}^{-3}$ was chosen for the HDPE (Guilhen et al., 2017).

$$
\begin{gathered}
m=\rho v, v_{v}=\frac{\left(\rho_{c t}+\rho_{c e}\right)}{\rho_{c t}} \cdot 100 V_{v}= \\
=\frac{\left(\rho_{c t}+\rho_{c e}\right)}{\rho_{c t}} \cdot 100
\end{gathered}
$$
development of the region (Santos et al., 2014). There was no chemical treatment of the materials used in this study in order to strengthen the sustainable character of the composite material.

To evaluate the influence of sisal fibres orientation on the mechanical properties of composites, two arrangements were used: woven and randomly arranged sisal fibres (Fig. 2).

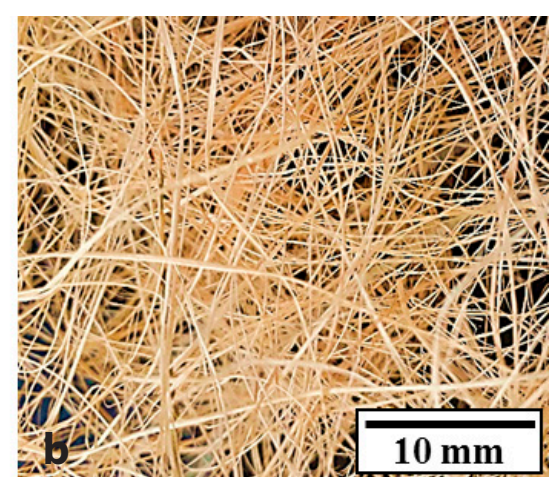

Fig. 2 (a) Woven sisal fibres at $\left(0^{\circ} / 90^{\circ}\right)$ and (b) randomly arranged sisal fibres where:

$$
\begin{aligned}
& m-\text { material mass }(\mathrm{g}) \\
& \rho-\text { material density }\left(\mathrm{g} \cdot \mathrm{cm}^{-3}\right) \\
& v \quad-\text { material volume }\left(\mathrm{cm}^{3}\right)
\end{aligned}
$$

The composite board dimensions were $190 \times 110 \mathrm{~mm}$ (length, width), and the total mass was nearly $105 \mathrm{~g}$. Woven sisal fibre-reinforced HDPE composites were made of HDPE layers at the faces and fibres at the centre. In case of randomly arranged sisal reinforcement, fibres were interleaved into three major layers of plastic in order to allow the formation of intermolecular bonds between the reinforcement gaps and HDPE. Non-uniform regions of the bags were discarded to minimize variations in the properties of the produced composites.

\section{Hot compression moulding}

The composites were moulded into boards by hot compression moulding, 


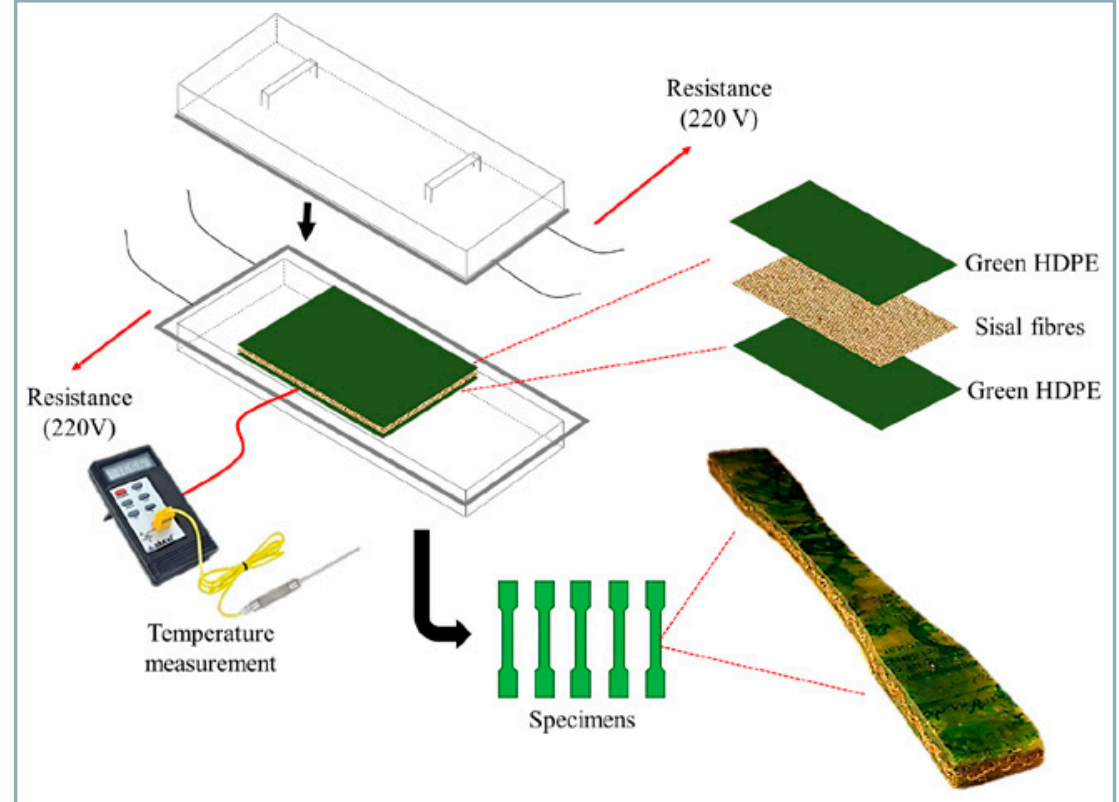

Fig. 3 Process of hot compression moulding to make sisal HDPE composites

as shown in Fig. 3; for these purposes, equipment specially developed for this study was utilized. It contained two electrical resistors $(2,000 \mathrm{~W}$ of power), each attached within blocks of refractory material $50 \mathrm{~mm}$ thick and covered by metal sheets.

The composites were moulded between two aluminium boards with dimensions of $550 \times 250 \times 10 \mathrm{~mm}$. In addition, an Armalon ${ }^{\circledR}$ (cover) protection was used to prevent chemical interactions between aluminium boards and composite materials. The pressure used to make the composites was approximately $5.46 \mathrm{kPa}$. It was calculated on the basis of the weight exerted by the upper block of the equipment and applied directly to the composite surface (board face). Preliminary experimental results indicated that lower working pressures were not effective for the purposes of the board moulding and compaction process.

The average temperature inside the mould was fixed at $185^{\circ} \mathrm{C}$. This temperature was selected on the basis of the exploratory testing and values provided in literature. Coutinho et al. (2003) stated that required temperature should exceed the HDPE melting point, which is approximately $135^{\circ} \mathrm{C}$. Composites heated to temperatures above $190^{\circ} \mathrm{C}$ were polyethylene bags with visible degradation aspects. When temperatures reached the value above $200{ }^{\circ} \mathrm{C}$, fibre degradation due of $13 \mathrm{~mm}$ were tested at $5 \mathrm{~mm} \cdot \mathrm{min}^{-1}$ speed. The specimens were shaped using a jigsaw machine. Five specimens were obtained from each board and ten specimens were tested from each experimental condition. The edges of the board were not used for testing. The mean value of each property was calculated from the five central results.

\section{Results and discussion}

\section{Composite manufacturing}

The cooling process has direct influence on the homogeneity of composite faces. When the material is removed at high temperatures, there is a rapid cooling and consequent solidification, resulting in physical heterogeneities in the composite faces. Moreover, there can occur a deformation of the board due to stretching phenomenon, caused by the increased resistance of the material resultant from the alignment of the polymeric chains (Barros and Branciforti, 2018). Therefore, the composites remained inside the mould for one hour until a temperature of $100{ }^{\circ} \mathrm{C}$ was reached (below the average crystallisation temperature, estimated between 116 and $124^{\circ} \mathrm{C}$ (Choudhury, 2008)). Once removed from the mould, the board was kept at room temperature $\left(25^{\circ} \mathrm{C}\right)$ until completely cooled. Fig. 4 shows that the manufacturing process used allows uniform flow between the gaps of the sisal fibres and enables a settled stiffness of the composite mechanical

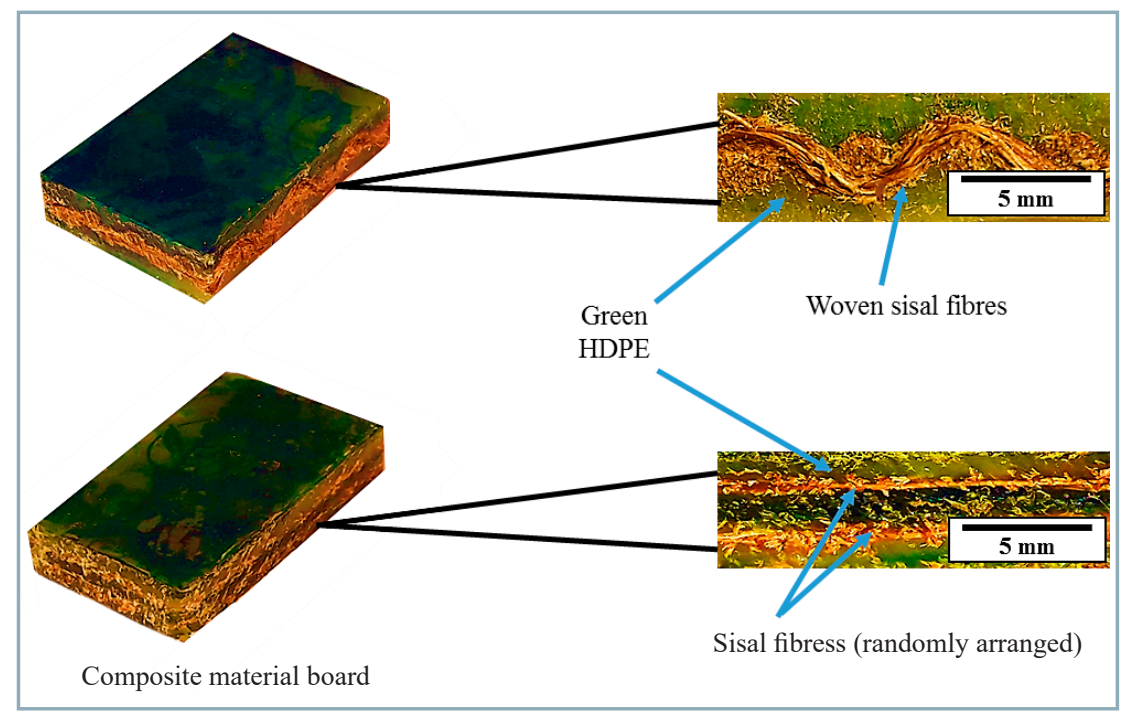

Fig. 4 Sisal fibre-reinforced green HDPE composite 
structure. Lateral section of a tensile test specimen shows structure homogeneity and quality of the cuts (Fig. 4).

\section{Mechanical tests}

Table 2 shows the results of tensile tests for each experimental condition. Pure green HDPE showed higher tensile strength than pure traditional HDPE, indicating the possibility of replacing the fossil polymer with green polymer.

Fig. 5 shows the stress-strain curves of different types of materials tested. These curves show typical examples of each experimental condition, because they were very similar. Composites with woven sisal fibres achieved higher ultimate strain than composites with randomly arranged

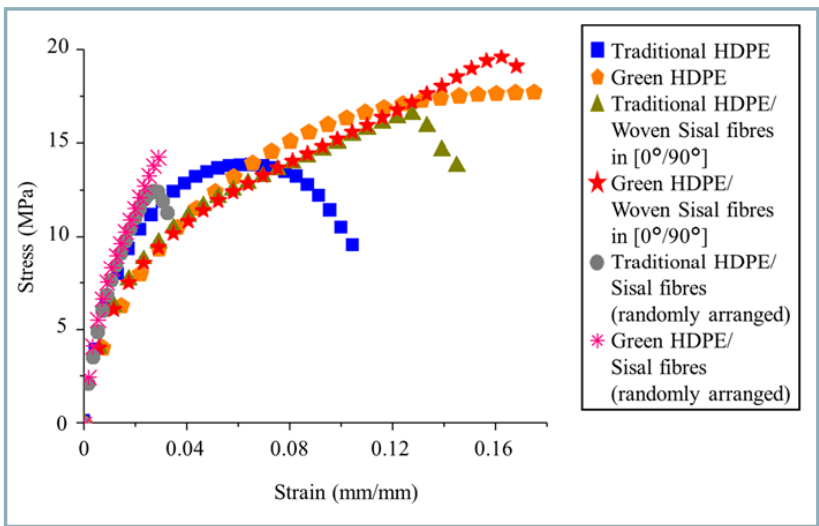

Fig. 5 Stress-strain curves for each condition

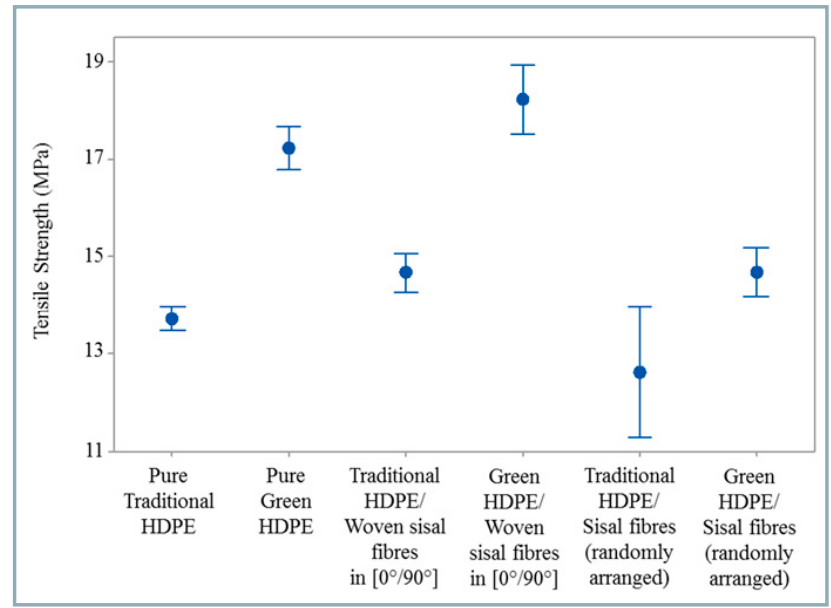

Fig. 6 Tensile strength of the specimens fibres, suggesting the influence of the reinforcement type on this mechanical property. Woven sisal fibre-reinforced HDPE composites demonstrated a quasi-linear behaviour in the plastic region, until reaching its ultimate strain.

The green HDPE composite reinforced with woven sisal fibres in $\left(0^{\circ} / 90^{\circ}\right)$ showed the highest tensile strength (Fig. 6) because of the influence of the relationship between fibre arrangement and direction of applied stress. Composites with randomly arranged sisal fibres showed lower tensile strength than other experimental arrangements, which can be explained by the load transfer mechanism.

Regarding the modulus of elasticity, composites with woven sisal fibres in $\left(0^{\circ} / 90^{\circ}\right)$ presented the lowest values from all experimental arrangements (Fig. 7), indicating a more ductile behaviour. Composites with randomly arranged sisal fibres had a larger contact surface with the matrix, improving the efficiency of interfacial adhesion, which ensures the transmission of mechanical loads (Jawaid et al., 2011).

Pure green HDPE specimens achieved higher ultimate strain than pure traditional HDPE (Fig. 8), indicating a more efficient process of alignment of the polymeric chains, which increased their resistance to mechanical stress applied in the direction of these chains (Barros and Branciforti, 2018). Composites with randomly arranged sisal fibres demonstrated high stiffness up to $2.5 \%$ in strain but ruptured after low plastic deformation.

The results show that although the woven sisal fibres in $\left(0^{\circ} / 90^{\circ}\right)$ had an increase in the composite tensile strength,

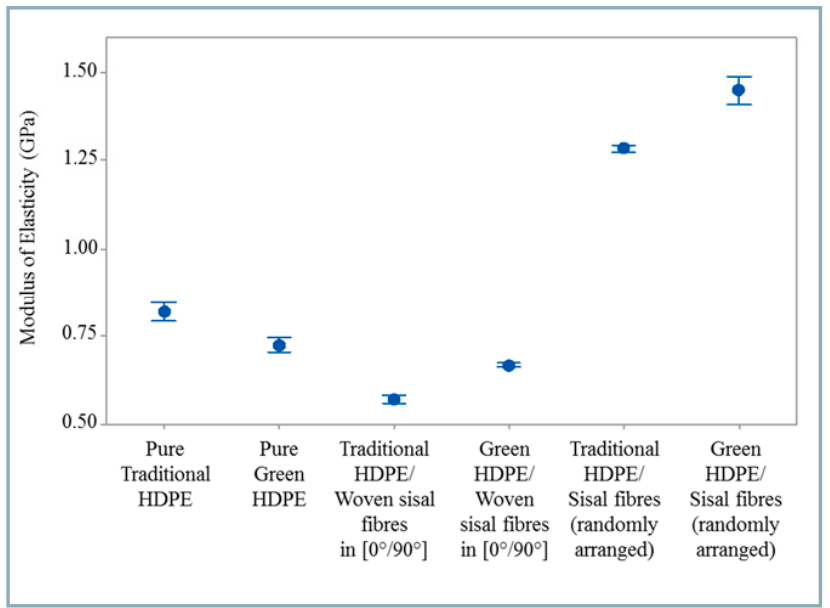

Fig. 7 Modulus of elasticity of the specimens

Table 2 Tensile tests results

\begin{tabular}{|l|c|c|c|}
\hline Experimental condition & Tensile strength $(\mathbf{M P a})$ & Modulus of elasticity (GPa) & Ultimate strain (\%) \\
\hline Pure Traditional HDPE & $13.72 \pm 0.56$ & $0.82 \pm 0.06$ & $6.12 \pm 0.66$ \\
\hline Pure Green HDPE & $17.22 \pm 1.13$ & $0.73 \pm 0.05$ & $18.10 \pm 1.93$ \\
\hline Traditional HDPE/Woven sisal fibres in $\left.\mathbf{0}^{\circ} / \mathbf{9 0}^{\circ}\right)$ & $14.71 \pm 1.24$ & $0.57 \pm 0.03$ & $11.77 \pm 2.21$ \\
\hline Green HDPE/Woven sisal fibres in $\left.\mathbf{( 0}^{\circ} / \mathbf{9 0}^{\circ}\right)$ & $18.29 \pm 1.84$ & $0.67 \pm 0.01$ & $15.65 \pm 0.57$ \\
\hline Traditional HDPE/Sisal fibres (randomly arranged) & $12.64 \pm 2.98$ & $1.29 \pm 0.02$ & $1.64 \pm 0.20$ \\
\hline Green HDPE/Sisal fibres (randomly arranged) & $14.70 \pm 1.13$ & $1.45 \pm 0.09$ & $2.84 \pm 0.35$ \\
\hline
\end{tabular}

*Five specimens were considered in the mean values 


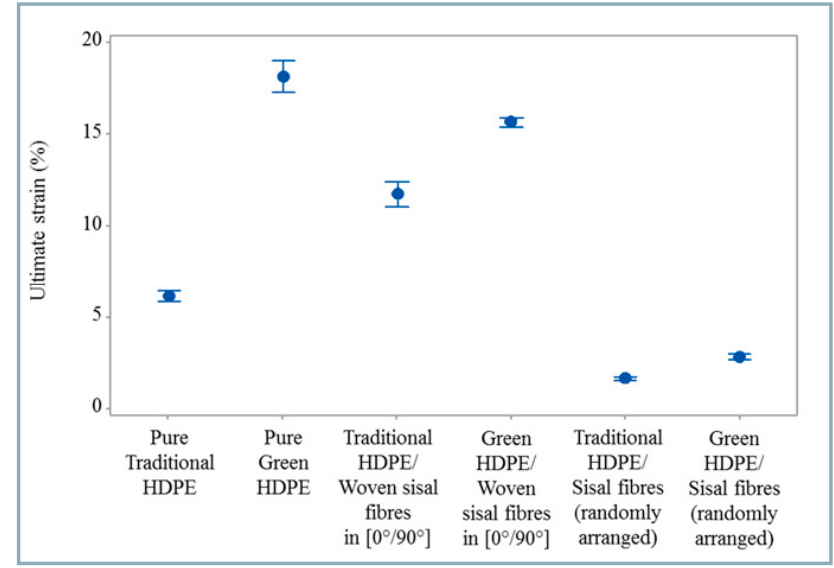

Fig. 8 Ultimate strain of the specimens

it caused the decrease in its stiffness. On the other hand, the randomly arranged sisal fibre-reinforced composites showed an opposite behaviour. The polyethylene was better included in the sisal fibre structure, resulting in a more compact and stiffer structure.

Figs. 9 and 10 show the main failure modes verified after tensile tests. A large plastic deformation in the matrix, as well as sisal fibres pull-out and delamination, were detected in woven sisal fibre-reinforced HDPE composites (Fig. 9). The results and the damage mechanisms signalized low adhesion in the interfacial zones of these composites. Plastic deformation was influenced by the alignment of the polymeric chains, which was caused by the material cooling during the manufacturing process (Mokhena and Luyt, 2014). In several cases, matrix breakage was also observed. Fibre pull-out and delamination was directly related to the interfacial adhesion failure (Jawaid et al., 2011).
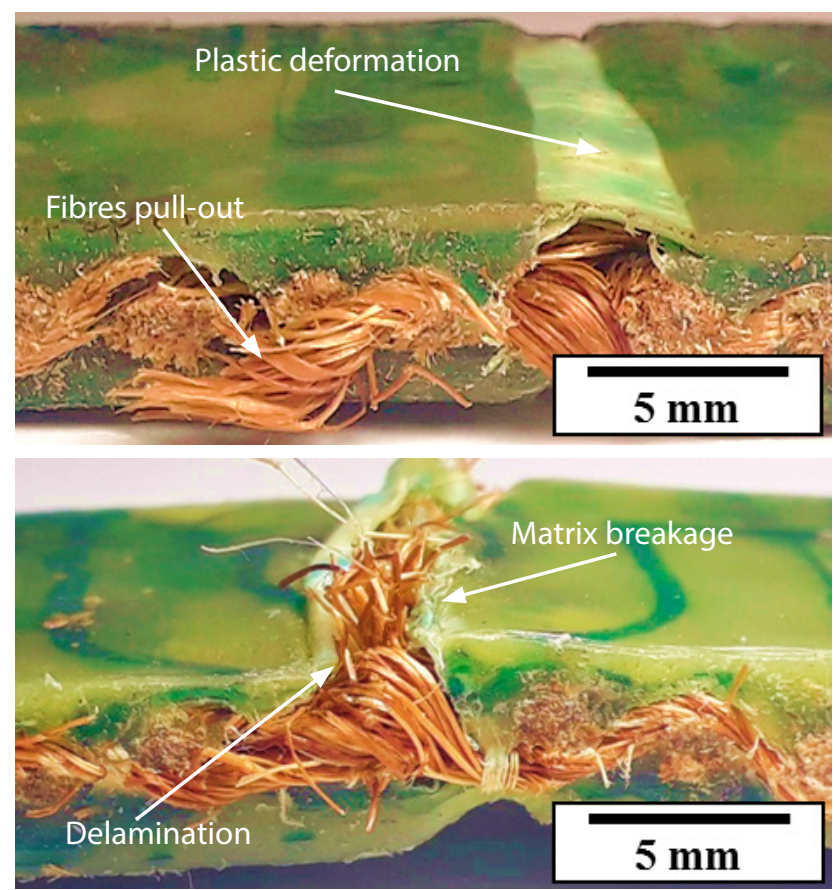

Fig. 9 Failure modes after tensile stress test of woven sisal fibre-reinforced green HDPE composites
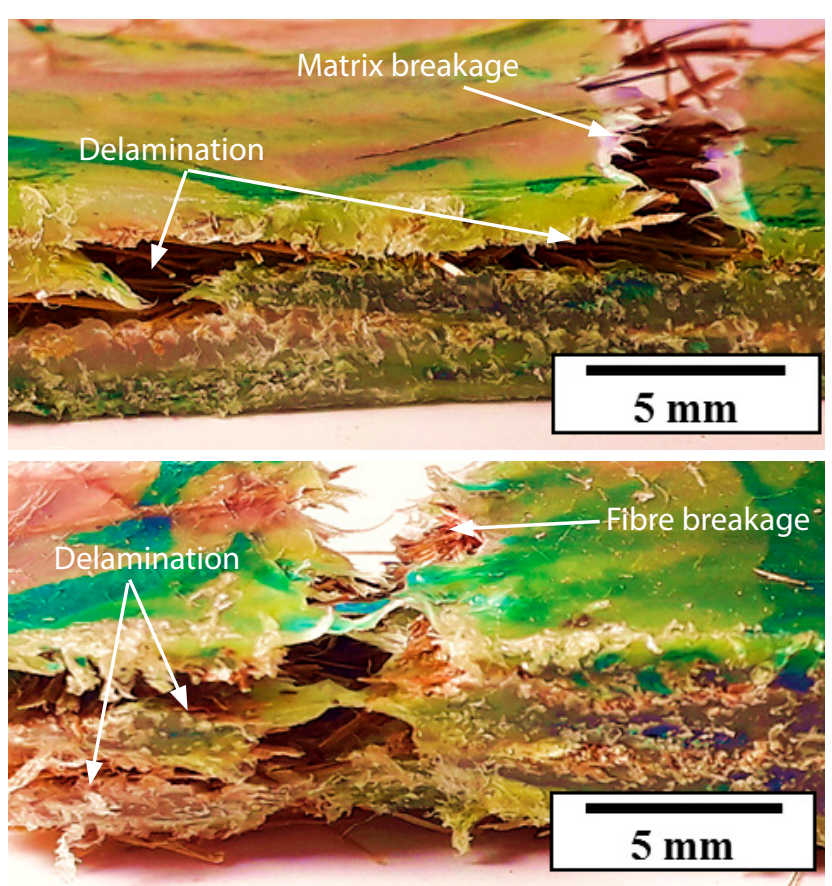

Fig. 10 Failure modes after tensile stress test of randomly arranged sisal fibre-reinforced green HDPE composites

In composites with randomly arranged sisal fibres, delamination was the predominant damage found (Fig. 10). Matrix and fibre breakage were also observed after tensile stress test. Sisal fibres have several hydroxyl groups in their chemical structure with a hydrophilic nature, and HDPE has also a hydrophobic nature, which negatively influences the load transfer between phases (Fig. 11), and neither fibres nor HDPE had been subjected to chemical treatment to improve the compatibilities and consequently the improvement of the mechanical properties, reaffirming the weak interfacial bond (Silva et al., 2013).

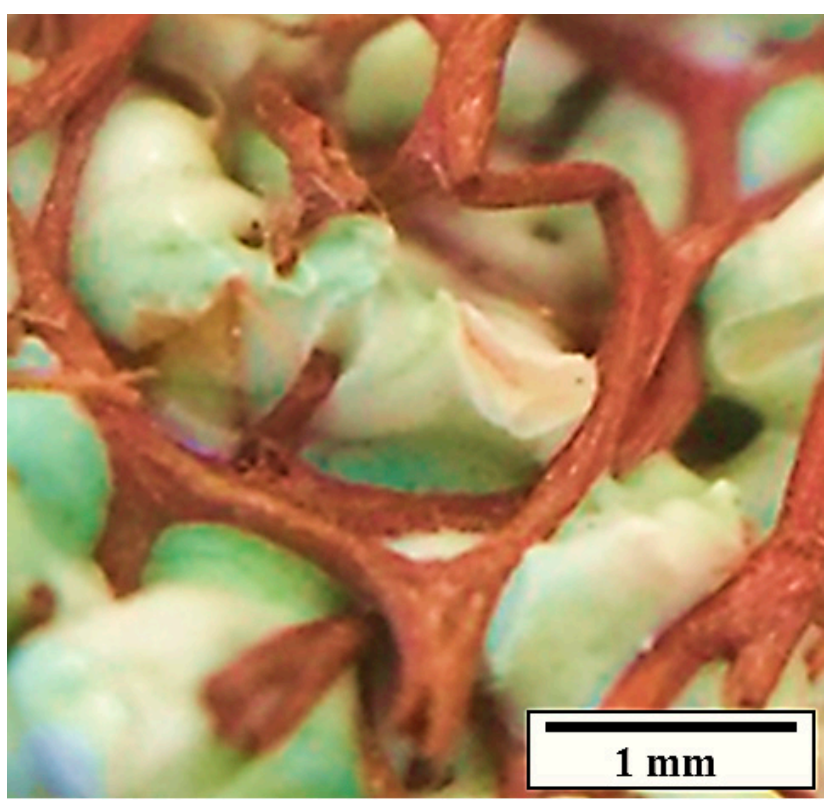

Fig. 11 Interfacial bonding of sisal HDPE composites 


\section{Conclusions}

In this study, green composites were manufactured using an easier and low-cost hot compression moulding in contrast to traditional methods of composites moulding.

Woven sisal fibre-reinforced green HDPE composites achieved higher tensile strength and lower modulus of elasticity in comparison to pure HDPE specimens. On the other hand, randomly arranged sisal fibre-reinforced green HDPE composites had higher values for modulus of elasticity than pure HDPE, as well as composites with woven sisal fibres.

The results showed that the use of these materials in structural applications, such as drywall and insulated panels, is possible. In order to prevent any premature failure during use, the success of this application depends directly on the product requirements. However, the main reason to use recycled polymers and natural fibres (without chemical treatment) is due to the possibility to produce a sustainable material able to isolate thermal and acoustic variations.

\section{Acknowledgments}

This study was financed in part by the CNPq, FAPEMIG and Coordenação de Aperfeiçoamento de Pessoal de Nível Superior - Brazil (CAPES) - Finance Code 001. In addition, the authors thank the Center for Innovation and Technology in Composites (Citec) at the Federal University of São João del-Rei (UFSJ) and the Post-Graduate Programme in Mechanical Engineering and the Department of Production Engineering at the Federal University of Minas Gerais (UFMG), for the structure and the support provided.

\section{References}

AHMAD, E. E. M. - LUYT, A. S. 2012. Effects of organic peroxide and polymer chain structure on mechanical and dynamic mechanical properties of sisal fiber reinforced polyethylene composites. In Journal of Applied Polymer Science, vol. 125, pp. 2216-2222.

AKINYEMI, B. A. - OMONIYI, T. E. - ADEYEMO, M. O. 2016. Prospects of coir fibre as reinforcement in termite mound clay bricks. In Acta Technologica Agriculturae, vol. 19, no. 3, pp. 57-62.

ASTM D638. 2014. Standard Test Method for Tensile Properties of Plastics. West Conshohocken, 13 pp.

BARROS, R. M. - BRANCIFORTI, M. C. 2018. Correlation between molecular orientation, crystallinity and permeability of biaxially oriented linear low-density polyethylene films. In Matéria (Rio de Janeiro), vol. 23, no. 1.

CHATTOPADHYAY, S. K. - SINGH, S. - PRAMANIK, N. - NIYOGI, U. K. - KHANDAL, R. K. - UPPALURI, R. - GHOSHAL, A. K. 2011. Biodegradability studies on natural fibers reinforced polypropylene composites. In Journal of Applied Polymer Science, vol. 121, no. 4 pp. 2226-2232.
CHOUDHURY, A. 2008. Isothermal crystallization and mechanical behavior of ionomer treated sisal/HDPE composites. In Materials Science and Engineering A, vol. 491, pp. 492-500.

COUTINHO, F. M. - MELLO, I. L. - MARIA, L. C. S. 2003. Polyethylene: main types, properties and applications. In Polímeros: Ciência e Tecnologia, vol. 13, no. 1, pp. 1-13.

FÁVARO, S. L. - GANZERLI, T. A. - DE CARVALHO NETO, A. G. V. - DA SILVA, O. R. R. F. - RADOVANOVIC, E. 2010. Chemical, morphological and mechanical analysis of sisal fiber-reinforced recycled highdensity polyethylene composites. In eXPRESS Polymer Letters, vol. 4, no. 8, pp. 463-473.

GUILHEN, A. - GADIOLI, R. - FERNANDES F. C. - WALDMAN, W. R. - PAOLI, M. A. D. 2017. High-density green polyethylene biocomposite reinforced with cellulose fibers and using lignin as antioxidant. In Journal of Applied Polymer Science, vol. 134, no. 35, pp. 45219-45228.

IBRAHIM, I. D. - JAMIRU, T. - SADIKU, E. R. - KUPOLATI, W. K. AGWUNCHA, S. C. - EKUNDAYO, G. 2016. Mechanical properties of sisal fibre-reinforced polymer composites: a review. In Composite Interfaces, vol. 23, no. 1, pp. 15-36.

JAWAID, M. - ABDUL KHALIL, H. P. S. - ABU BAKAR, A. 2011. Woven hybrid composites: Tensile and flexural properties of oil palmwoven jute fibres based epoxy composites. In Materials Science and Engineering A, vol. 528, pp. 5190-5195.

MOHD RAFEE, S. N. A. - LEE, Y. L. - JAMALLUDIN, M. R. - ABDUL RAZAK, N. - MAKHTAR, N. I. - ISMAIL, R. I. 2019. Effect of different ratios in biomaterials to banana peels on the weight loss of biodegradable pots. In Acta Technologica Agriculturae, vol. 22, no. 1, pp. 1-4.

MOKHENA, T. C. - LUYT, A. S. 2014. Investigation of polyethylene/ sisal whiskers nanocomposites prepared under different conditions. In Polymer Composites, vol. 35, no. 11, pp. 2221-2233.

PLATI, C. 2019. Sustainability factors in pavements materials, design and preservation strategies: A literature review. In Construction and Building Materials, vol. 211, pp. 539-555.

SANTOS, A. F. - MARTINS, C. Y. - SANTOS, P. O. - CORRÊA, E. B. BARBOSA, H. R. - SANDOVAL, A. P. - OLIVEIRA, L. M. - SOUZA, J. T. - SOARES, A. C. 2014. Diazotrophic bacteria associated with sisal (Agave sisalana Perrine ex Engelm): potential for plant growth promotion. In Plant and Soil, vol. 385, pp. 37-48.

SILVA, L. J. - CAMPOS RUBIO, J. C. - PANZERA, T. H. - BORGES, P. H. R. 2013. The effect of silica microparticles and maleic anhydride on the physic-mechanical properties of epoxy matrix phase. In Science and Engineering of Composite Materials, vol. 20, pp. 203-208.

ZHAO, X. - LI, R. K. Y. - BAI, S.-L. 2014. Mechanical properties of sisal fiber reinforced high density polyethylene composites: Effect of fiber content, interfacial compatibilization, and manufacturing process. In Composites: Part A, vol. 65, pp. 169-174. 